\title{
Genetic variations among two Egyptian mint species (Mentha spicata and Mentha piperita) using random amplified Polymorphic DNA markers
}

\author{
Medhat H. Hashem ${ }^{1}$, Islam M. H. Rizk ${ }^{2 *}$ and Reham M. Abd El-Azeem ${ }^{2}$ \\ ${ }^{1}$ Animal Biotechnology Department, Genetic Engineering and Biotechnology Research Institute \\ (GEBRI), University of Sadat City, Sadat City, Egypt \\ 2 Environmental Biotechnology Department, Genetic Engineering and Biotechnology Research \\ Institute (GEBRI), University of Sadat City, Egypt \\ *Corresponding author: E-mail address: islam_rizk2@yahoo.com.
}

\begin{abstract}
In the present study, RAPD-PCR was used for identification of two mint species (Mentha spicata and Mentha piperita) collected from Egypt and studying the genetic variations among them. RAPD-PCR was conducted using ten oligonucleotide primers. The ten primers succeeded in amplifying of DNA fragments for the two Mentha species. These primers produced multiple fragments profiles ranging from 3 to 19 fragments. The polymorphism levels differed from primer to another. The number of polymorphic fragments ranged from 0 to 66.29 per primer. The total number of the obtained fragments from the ten primers was 83 fragments with 39 polymorphic fragments $(46.98 \%)$ across the two mint species. Forty percent of primers did not exhibit any polymorphism. This study provides evidence that RAPD Markers can be used as an efficient tool for the detection of the genetic variations and identifications of different mint species.
\end{abstract}

Keywords: Mentha species, RAPD-PCR, genetic differences, molecular markers

\section{INTRODUCTION}

Mint plants are perennial herbs. They are cultivated for their aromatic oils (produced as secondary metabolites) that are important in a great variety of products and for medicinal and aromatic purposes. (Vining et al., 2017 and Ahmad, 2018).Mint belong to the Genus Mentha, family Labiatae. The genus which includes about 25 to 30 species is widely distributed in the temperate areas (Douhan and Johnson, 2001, Rabia et al., 2015, Vining et al., 2017 and Ahmad, 2018). In Egypt, there are three species of MenthaM. spicata, $M$. longifolia and $M$. pulegium. $M$. spicata (spearmint) is used in food flavoring and cultivated for the volatile oils. Also, M. piperita (peppermint) is widely cultivated in Egypt for its economic importance (Mohammed, 1986 and Rabia et al., 2015).

To examine the diversity of Mentha, different methods have been used in the past using morphological, chemical, cytological, and chromosomal markers. The genus polymorphism needs accurate taxonomic methods with modern technologies (Ahmad, 2018). 
The using of DNA markers techniques can generate a profile or "fingerprint" unique to a particular species (Fenwick and Ward, 2001 and Ahmad, 2018). Randomly amplified polymorphic DNA (RAPD) analysis is one of these markers. In RAPD, short DNA primers are used to generate genome-specific patterns by polymerase chain reaction (Williams et al., 1990). RAPD-PCR has been used for cultivari dandification and genetic analysis in a different plants (Nazar and Mahmood, 2011; Mahmood et at., 2011, Abd El-Azeem et al., 2011 and Ibrahim et al., 2014)

In the present study, RAPD-PCR was used for identification of two mint species (Mentha spicata and Mentha piperita) collected from Egypt and studying the genetic variations among them.

\section{MATERIALS AND METHODS}

\section{Experimental plants}

Mint plants were obtained from

Genetic Engineering and Biotechnology

Research Institute (GEBRI), University of

Sadat city, Sadat city, Egypt.

\section{DNA extraction}

DNA extraction kit from Fermentas (Gene JETTM, plant genomic DNA purification mini kit) was used for genomic DNA extraction. Polyvinyl pyrrolidone (PVP) was added to lysis Buffer before used at $2 \%(W / V)$ final concentration. DNA was quantified by using Gene quant spectrophotometer. The quality was further detected through $1 \%$ agarose gel electrophoresis.

\section{RAPD analysis}

RAPD-PCR was conducted using ten oligonucleotide primers (Table, 1) that were chosen from the Operon Kit (Operon Technologies Inc., Alabameda, CA). PCR amplification was carried out in $20 \mu$ volume contains $30 \mathrm{ng}$ of DNA, $0.4 \mu \mathrm{M}$ of primer, 200 $\mu \mathrm{M}$ of each dNTP, $2 \mathrm{mM} \mathrm{MgCl} 2,1 \times \mathrm{PCR}$ buffer and $0.8 \mathrm{U}$ of Tag DNA polymerase. PCR amplification was performed by using Thermal cycler of Biometra T1 gradient with the following steps: $94^{\circ} \mathrm{C}$ for $5 \mathrm{~min}$, then $94^{\circ} \mathrm{C}$ for 1 $\min , 35^{\circ} \mathrm{C}$ for $40 \mathrm{sec}$, and $72^{\circ} \mathrm{C}$ for $1 \mathrm{~min}$ for 35 cycles. A final extension cycle was performed at $72^{\circ} \mathrm{C}$ for $7 \mathrm{~min}$ (Gebhart, et al., 1991 and Ibrahim et al., 2014). PCR products were tested on $1.5 \%$ ethidium bromide stained agarose gel electrophoresis. The products were separated at 90 volts for $1.0 \mathrm{hr}$ in I X TAE buffer.

\section{Data analysis}

The obtained fragments were scored as present/absent using Phoretix 1D advanced Version 4.00 (Phoretix International, Newcastle upon Tyne, UK). Similarity and coefficients clustering methods were tested using version 2 of the program NTSYSpc (Applied Biostatistics, USA). Clustering methods WPGMA, UPGMA, Complete-link, and Singlelink were used in all possible combinations with the similarity coefficients Jaccard, Dice, and simple matching. (Gebhart et al., 1991). 
Table1.The nucleotide sequences of primers that were used for RAPD analysis.

\begin{tabular}{|c|c|}
\hline Primer code & Sequence(5 -3 $^{\prime}$ ) \\
\hline OPA-15 & TTCCGAACCC \\
\hline OPA-19 & CAAACGTCGG \\
\hline OPA-06 & GGTCCCTGAC \\
\hline OPA-17 & GACCGCTTGT \\
\hline OPA-04 & AATCGGGCTG \\
\hline OPA-11 & CAATCGCCGT \\
\hline OPB-06 & TGCTCTGCCC \\
\hline OPC-01 & TTCGAGCCAG \\
\hline OPC-09 & CTCACCGTCC \\
\hline OPC-20 & ACTTCGCCAC \\
\hline
\end{tabular}

\section{RESULTS}

In this study genetic, variations of the two mint species (Spearmint and Peppermint) was studied by using RAPD markers. Ten primers were used; OPA-11, OPA-04, OPA-06, OPA-15, OPA-17, OPA-19, OPB-06 OPC-01, OPC-09 and OPC-20 (Table 2 and Figure 2).

The ten primers succeeded in amplifying of DNA fragments for the two Mentha species. These primers produced multiple fragments profiles ranging from 3 to 19 fragments. The polymorphism levels differed from primer to another. The number of polymorphic fragments ranged from 0 to 66.29 per primer. The total number of the obtained fragments from the ten primers was 83 fragments with 39 polymorphic fragments (46.98\%) across the two mint species. The highest number of amplified fragments (19) was obtained from primer OPC-20, while the primer OPA-17 exhibited the lowest number (3). The primer OPC-09 gave the highest \% of polymorphism (69.23) whereas the primers, OPA-11, OPA-04, OPA-15 and OPA-17 did not exhibit any polymorphism.

Table2.The obtained amplified fragments from the DNAs of the two mint species.

\begin{tabular}{|c|c|c|c|c|c|c|c|c|c|c|c|c|c|c|c|}
\hline \multirow[b]{2}{*}{ Band } & \multicolumn{3}{|c|}{ OPB-06 } & \multicolumn{3}{|c|}{ OPA-11 } & \multicolumn{3}{|c|}{ OPA-04 } & \multicolumn{3}{|c|}{ OPA-06 } & \multicolumn{3}{|c|}{ OPC-20 } \\
\hline & $\begin{array}{c}\text { Size in } \\
\text { bp }\end{array}$ & $\mathrm{S} 1$ & S2 & $\begin{array}{c}\text { Size in } \\
\text { bp }\end{array}$ & S1 & $\mathrm{S} 2$ & $\begin{array}{c}\text { Size in } \\
\text { bp }\end{array}$ & $\mathrm{S} 1$ & $\mathrm{~S} 2$ & $\begin{array}{c}\text { Size in } \\
\text { bp }\end{array}$ & $\mathrm{S} 1$ & S2 & $\begin{array}{c}\text { Size in } \\
\text { bp }\end{array}$ & S1 & S2 \\
\hline 1 & 1454 & 0 & 1 & 2984 & 1 & 1 & 1454 & 1 & 1 & 1664 & 1 & 1 & 1454 & 1 & 0 \\
\hline 2 & 1271 & 1 & 1 & 2384 & 1 & 1 & 1271 & 1 & 1 & 1271 & 1 & 1 & 1329 & 1 & 0 \\
\hline 3 & 970 & 1 & 1 & 1904 & 1 & 1 & 970 & 1 & 1 & 1110 & 1 & 1 & 1110 & 1 & 1 \\
\hline 4 & 811 & 1 & 0 & 1740 & 1 & 1 & 811 & 1 & 1 & 970 & 1 & 1 & 928 & 0 & 1 \\
\hline 5 & 775 & 0 & 1 & 1591 & 1 & 1 & - & - & - & 848 & 1 & 1 & 741 & 1 & 1 \\
\hline 6 & 708 & 1 & 0 & 1454 & 1 & 1 & - & - & -- & 741 & 1 & 1 & 677 & 1 & 0 \\
\hline 7 & 677 & 1 & 0 & 1215 & 1 & 1 & - & - & - & 541 & 1 & 1 & 648 & 1 & 1 \\
\hline 8 & 648 & 0 & 1 & 1110 & 1 & 1 & - & - & - & 473 & 1 & 1 & 592 & 1 & 0 \\
\hline 9 & 541 & 1 & 1 & 848 & 1 & 1 & - & - & - & 395 & 1 & 1 & 566 & 0 & 1 \\
\hline 10 & 473 & 1 & 1 & 775 & 1 & 1 & - & - & - & 345 & 1 & 1 & 541 & 1 & 0 \\
\hline 11 & 432 & 0 & 1 & 708 & 1 & 1 & - & - & - & 288 & 1 & 1 & 494 & 1 & 0 \\
\hline
\end{tabular}




\begin{tabular}{|c|c|c|c|c|c|c|c|c|c|c|c|c|c|c|c|}
\hline & \multicolumn{4}{|c|}{ OPB-06 } & \multicolumn{3}{c|}{ OPA-11 } & \multicolumn{3}{c|}{ OPA-04 } & \multicolumn{3}{c|}{ OPA-06 } & \multicolumn{3}{c|}{ OPC-20 } \\
\cline { 2 - 16 } Band & $\begin{array}{c}\text { Size in } \\
\text { bp }\end{array}$ & S1 & S2 & $\begin{array}{c}\text { Size in } \\
\text { bp }\end{array}$ & S1 & S2 & $\begin{array}{c}\text { Size in } \\
\text { bp }\end{array}$ & S1 & S2 & $\begin{array}{c}\text { Size in } \\
\text { bp }\end{array}$ & S1 & S2 & $\begin{array}{c}\text { Size in } \\
\text { bp }\end{array}$ & S1 & S2 \\
\hline 12 & 395 & 1 & 1 & 566 & 1 & 1 & - & - & - & 230 & 1 & 1 & 473 & 0 & 1 \\
\hline 13 & 345 & 1 & 1 & 494 & 1 & 1 & - & - & - & 192 & 1 & 1 & 413 & 1 & 1 \\
\hline 14 & 316 & 0 & 1 & 452 & 1 & 1 & - & - & - & 168 & 0 & 1 & 395 & 0 & 1 \\
\hline 15 & 302 & 1 & 1 & 395 & 1 & 1 & - & - & - & 147 & 1 & 1 & 361 & 1 & 0 \\
\hline 16 & 264 & 1 & 1 & 302 & 1 & 1 & - & - & - & - & - & - & 316 & 1 & 1 \\
\hline 17 & 201 & 1 & 1 & 211 & 1 & 1 & - & - & - & - & - & - & 230 & 1 & 1 \\
\hline 18 & - & - & - & 176 & 1 & 1 & - & - & - & - & - & - & 192 & 1 & 0 \\
\hline 19 & - & - & - & - & - & - & - & - & - & - & - & - & 161 & 1 & 1 \\
\hline D.F & & 14 & 12 & & 18 & 18 & & 4 & 4 & & 14 & 15 & & 15 & 11 \\
\hline P.F(\%) & & 47.05 & & \multicolumn{1}{|c|}{ Zero } & & \multicolumn{1}{|c|}{ Zero } & & 6.66 & & 63.15 \\
\hline
\end{tabular}

\begin{tabular}{|c|c|c|c|c|c|c|c|c|c|c|c|c|c|c|c|}
\hline \multirow[b]{2}{*}{ Band } & \multicolumn{3}{|c|}{ OPC-01 } & \multicolumn{3}{|c|}{ OPA-19 } & \multicolumn{3}{|c|}{ OPA-15 } & \multicolumn{3}{|c|}{ OPA-09 } & \multicolumn{3}{|c|}{ OPA-17 } \\
\hline & Size in bp & S1 & S2 & Size in bp & S1 & S2 & Size in bp & S1 & S2 & $\begin{array}{l}\text { Size in } \\
\text { bp }\end{array}$ & S1 & S2 & Size in bp & S1 & S2 \\
\hline 1 & 670 & 1 & 1 & 854 & 1 & 1 & 1390 & 1 & 1 & 1532 & 1 & 0 & 500 & 1 & 1 \\
\hline 2 & 579 & 1 & 1 & 775 & 0 & 1 & 1261 & 1 & 1 & 1261 & 1 & 1 & 323 & 1 & 1 \\
\hline 3 & 476 & 0 & 1 & 607 & 1 & 0 & 941 & 1 & 1 & 1201 & 1 & 0 & 148 & 1 & 1 \\
\hline 4 & 454 & 1 & 1 & 525 & 1 & 1 & 854 & 1 & 1 & 1038 & 0 & 1 & - & - & - \\
\hline 5 & 392 & 1 & 0 & 476 & 1 & 1 & 775 & 1 & 1 & 941 & 0 & 1 & - & - & - \\
\hline 6 & 356 & 1 & 1 & 432 & 1 & 1 & 638 & 1 & 1 & 813 & 1 & 1 & - & - & - \\
\hline 7 & 307 & 0 & 1 & 356 & 0 & 1 & 579 & 1 & 1 & 579 & 1 & 1 & - & - & - \\
\hline 8 & 265 & 1 & 1 & 339 & 1 & 0 & 476 & 1 & 1 & 500 & 1 & 1 & - & - & - \\
\hline 9 & 198 & 1 & 1 & 279 & 1 & 1 & 392 & 1 & 1 & 454 & 0 & 1 & - & - & - \\
\hline 10 & - & - & - & 198 & 0 & 1 & 356 & 1 & 1 & 392 & 1 & 0 & - & - & - \\
\hline 11 & - & - & - & 122 & 0 & 1 & 279 & 1 & 1 & 373 & 0 & 1 & - & - & - \\
\hline 12 & - & - & - & 87 & 1 & 1 & - & - & - & 323 & 0 & 1 & - & - & - \\
\hline 13 & - & - & - & - & - & - & - & - & - & 265 & 0 & 1 & - & - & - \\
\hline D.F & & 7 & 8 & & 8 & 10 & 5 & 11 & 11 & & 7 & 10 & & 3 & 3 \\
\hline P.F(\%) & & 33 & & & & 0 & & & & & & & & & \\
\hline
\end{tabular}

S1: spearmint specie, S2: peppermint specie, D. F: detectable fragments, P. F (\%): polymorphic fragments percent. Total P.F $(\%)=46.98$. 


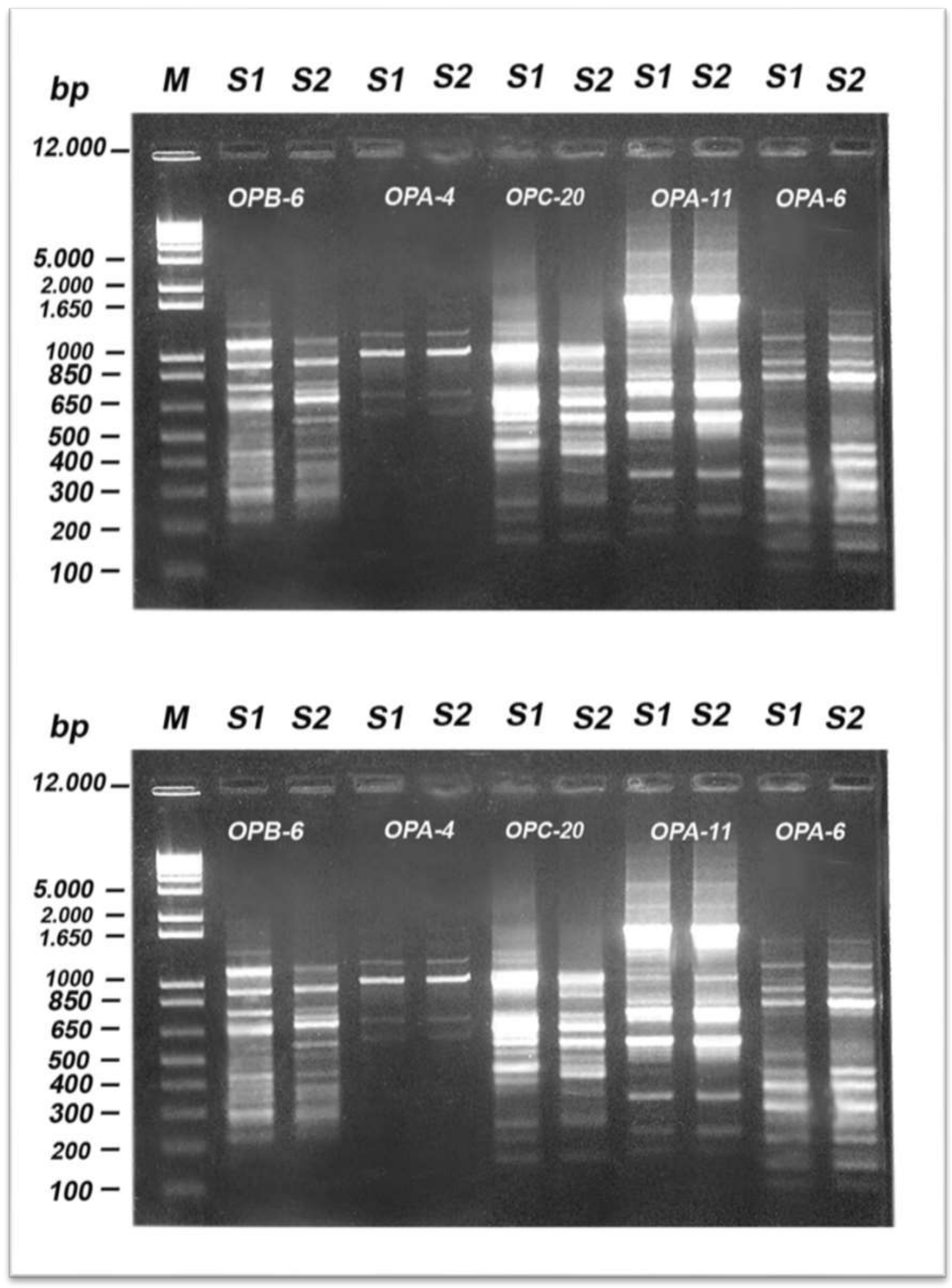

Figure 2. RAPD-PCR analysis of the two mint species by using ten random primers.

M: DNA marker, S1:Spearmint and S2:Peppermint 


\section{DISCUSSION}

The study of genetic diversity of plants is the process by which the difference among the individuals or populations is detected by a specific genetically technique or a combination of such techniques. The most important data is that obtained by DNA based marker and can be used to identify different genomes (Abd ElAzeem et al., 2011).

Worldwide, many DNA based marker have been used to identify the different genotypes of plants such as RAPD that is the simplest test of all recently applied DNA-based markers for plant identification (Trifi et al., 2000and Ibrahim et al., 2014).

In the present work, ten RAPD primers were used to study the genetic variation between two mint species (Mentha spicata and Mentha piperita) from Egypt. The obtained data indicated that some primers exhibit high percentage of polymorphism (OPC-20 and OPA-9). As well as, primers such as OPA-11, OPA-04, OPA-15 and OPA-17 did not exhibit any polymorphism. These results support the finding of Rabia et al. (2015). The high percentage of polymorphism indicated that the used primer can detect more genetic differences between the studied mint species than others. Fenwick and Ward, (2001)used
RAPD markers for cultivar identification in Mint. They reported that some RAPD markers primers that gave percentage of polymorphism can be used in mint to differentiate among species and among genotypes within a species. The results of the present study indicated that $40 \%$ of the used primers (4 from 10 primers) did not give any polymorphism. This lack of variation between the studied mint species suggests a very high degree of genetic similarity. On other hand $60 \%$ of primers exhibit polymorphic fragments between the two species such as OPC-09 primer that gave the highest percent of polymorphism (69.23). Rabia et al. (2015)found that the polymorphism produced from the used primers ranged from low to high level (50 to $92 \%$, respectively). Gobert et al. (2006) and Rabia et al. (2015)reported that DNA based studies indicated that mint species can be genetically distinguished.

In conclusion, this study provides evidence that RAPD Markers can be used as an efficient tool for the detection of the genetic variations and identifications of different mint species. The same conclusion was reported by Heikal et al. (2007) and Rabia et al. (2015 and Ahmad et al. 2018). 


\section{REFERENCES}

Abd El-Azeem, R. M., Hashem, M. H. and A.

A. Hemeida (2011). Identification and genetic similarity analysis of Date Palm (Phoenix dactylifera L.) collected from different regions In Siwa oasis using morphologically traits and molecular markers. Egyptian Journal of Genetics and Cytology, 40: 281-300.

Ahmad, I., Ullah khan, S., A., Khan, Amjad, M. S. and F. Abbasi (2018). Reassessment of Mentha Species from Kunhar River Catchment Using Morphological and Molecular Markers. Anadolu J. of AARI, 28 (1):6 - 12

Douhan, L.I., and D.A. Johnson, (2001).Vegetative compatibility and pathogenicity of Verticillium dahliae from spearmint and peppermint. Plant Disease, 85(3): 297-302

Fenwick, A.L. and S.M. Ward (2001). Use of random amplified polymorphic DNA markers for cultivar Identification in Mint. Horticulture, 36(4):761-764.

Foster, S. (1996).Peppermint; Mentha. American Botantical, Councilbotantical Series, 306: 3-8.

Gebhart, C. E., A. Baron, T. Debener, B. Walkameier, M. M. Ganal, S. T. anksely and F. Salamini (1991). RFLP maps of potato and their alignment with the homologues tomato genome. Theor. Appl. Gent., 83: 49-57

Heikal,H.A.,Y. Mabrouk,O. M.Badawy, A.ElShehawyand E.A.Badr (2007).
Fingerprinting

Egyptian gramineae species using Random Amplified Polymorphic DNA (RAPD) and Inter-Simple Sequence Repeat (ISSR) markers. Res. J. Cell Mol. Biol., 1:23-30.

Ibrahim, I. A., Hashem, M. H., Hemeida, A. A., Hassan, M. M. and A. I. A. Maksoud (2014). Characterization of genetic diversity of Date palm (Phoenix dactylifera L.) cultivars collected from New Valley governorate (EIKharga and Dakhleh) based on morphological variability and molecular markers. Life Sci. J., 11 (11): 879-889.

Mahmood, T., A. Siddiqua, A. Rasheed and N.Nazar (2011). Evaluation of genetic diversity in different Pakistani wheat landraces. Pak. J.Bot., 43:1233-1239.

Nazar, N.and T. Mahmood (2011). Morphological and molecular characterization of selected firtemisia species from raw alakot, Azad Jammu and Kashmir. Acta Physiologiae Plantarum, 33:625633.

RabiaM. M., OmneyaF. A. and Y.M. Sayed (2015). Comparative Study for Some Mentha Species and Varietie sunder Sandy Soil Conditions. Journal of Applied Science, 15(2):355-366.

Tucker, A.O., H. Hendriks, R. B. and D. E. Fairbrothers (1991). The origin of Mentha $\mathrm{x}$ gracilis (Lamiaceae). II. 
Essential oils. Econ. Bot. 45:100115.

Vining K.J., Johnson S.R., Ahkami A., Lange I., Parrish A.N., Trapp S.C., Croteau R.B., Straub S.C.K., Pandelova I., and B.M. Lange (2017). Draft genome Sequence of Mentha longifolia and development of resources for
Mint cultivar improvement. Mol. Plant. 10, 323-339.

Williams, J.K.G., A. Kubelik, K.L. Livak, J.A. Rafalski, and S.V. Tingey (1990). DNA polymorphisms amplified by arbitrary primers are useful as genetic markers. Nucleic Acids Res. 18:6531-6535. 